\title{
Comparison of diagnostic peritoneal lavage and focused assessment by sonography in trauma as an adjunct to primary survey in torso trauma: a prospective randomized clinical trial
}

\author{
Sunil Kumar, M.S., Abhay Kumar, M.S., Mohit Kumar Joshi, M.S., Vinita Rathi, M.D.
}

Department of Surgery, University College of Medical Sciences, Delhi, India

\begin{abstract}
BACKGROUND: Lately, Focused Assessment with Sonography in Trauma (FAST) is preferred over diagnostic peritoneal lavage (DPL) as adjunct to primary survey. However, this is not evidence-based as there has been no randomized trial.

METHODS: In this study, 200 consecutive torso trauma patients meeting inclusion criteria were randomized to undergo either DPL or FAST. The results were then compared with either contrast enhanced computerized tomography (CECT) (in patients managed non-operatively) or laparotomy findings (in patients undergoing operative treatment). Outcome parameters were: result of the test, therapeutic usefulness, role in diagnosing bowel injury and time taken to perform the procedure.

RESULTS: Two hundred patients with a mean age of 28.3 years were studied, 98 in FAST and 102 in DPL group. 104 sustained blunt trauma and 76 sustained penetrating trauma due to stabbing. In addition, 38 (38.7\%) were FAST positive and 48 (47\%) were DPL positive ( $p=0.237$, not significant). As a guide to therapeutically beneficial laparotomy, negative DPL was better than negative FAST. For non-operative decisions, positive FAST was significantly better than positive DPL. DPL was significantly better than FAST in detecting as well as not missing the bowel injuries. DPL took significantly more time than FAST to perform.
\end{abstract}

CONCLUSION: This study shows that DPL is better than FAST.

Key words: Diagnostic peritoneal lavage; focused assessment with sonography in trauma; torso trauma.

\section{INTRODUCTION}

Physical examination of a patient's abdomen with torso trauma is important but frequently unreliable for assessment of internal injuries due to the inaccessibility of pelvic region, upper abdominal and retroperitoneal organs to palpation, associated severe injuries, ${ }^{[1]}$ and altered mental status consequent to head injury, drugs or alcohol. ${ }^{[2]}$ To overcome this difficulty, several diagnostic modalities have been used as adjunct to

Address for correspondence: Dr. Mohit Kumar Joshi,

C-I/I20I, Olive County, Sec-5, Vasundhara 201012 Ghaziabad, UP, India

Tel: +9| I20-6768837 E-mail: drmohitjoshi@gmail.com

Qucik Response Code

Ulus Travma Acil Cerr Derg

20I4;20(2): $101-106$

doi: $10.5505 /$ tjtes.20I4.37336

Copyright 2014

TJTES the primary survey. These include focused assessment sonography in trauma (FAST), diagnostic peritoneal lavage (DPL), computed tomography (CT) scan and laparoscopy. ${ }^{[3]}$

FAST has emerged as a useful diagnostic tool. ${ }^{[4-6]}$ This limited ultrasound scan directed at detecting intra-peritoneal/pericardial fluid is economical, non-invasive, rapid, and repeatable. ${ }^{[7,8]}$ The greatest advantages of FAST is that it can be done at bedside without disturbing resuscitation. ${ }^{[7]}$ FAST has sensitivity between $80-85 \%$ and specificity of $97-100 \%$. [9] However, it may not be accurate in obese patients, in patients with ileus, or subcutaneous emphysema. Further, it is an operator dependent technique and does not differentiate between blood and free bowel contents.

On the other hand, DPL can differentiate between blood and free bowel contents. It is an invasive, rapid, accurate, bed-side procedure, and the most sensitive tool to determine presence of intra-abdominal injuries. ${ }^{[9]}$ Even though it has low specificity, DPL has been shown to be more efficient than CT scan in identifying patients that require surgical exploration. ${ }^{[10]}$ Like FAST a positive DPL does not necessarily mandate 
immediate laparotomy in a patient with stable hemodynamics. ${ }^{\left[{ }^{\prime \prime}\right]}$ However, unlike FAST this is non-repeatable, takes longer to perform, and alters subsequent physical examination of the abdomen. DPL may be contraindicated in patients with deranged coagulation profile, previous laparotomy, marked obesity, and advanced pregnancy.

Thus, it appears that FAST and DPL may have their own relative merits and de-merits. The current trend to prefer FAST over DPL remains unjustified in the absence of any prospective randomized trial. We took this opportunity to compare these two diagnostic procedures, which is to our knowledge the first to investigate the specific attributes of FAST and DPL by conducting a randomized-clinical trial (RCT).

\section{MATERIALS AND METHODS}

This prospective randomized clinical study was conducted from November 2009 to April 2012 in the Department of Surgery of a large volume tertiary care teaching hospital. The study was approved by the local ethical committee. Written informed consent for inclusion was obtained from patients or their family members (for minor and patients with altered sensorium).

Criteria for exclusion in the study were: age younger than 12 years or more than 65 years, gun-shot wounds, patients with unstable hemodynamics, isolated penetrating abdominal trauma, clinical features of peritonitis at presentation, free gas under the diaphragm, impaled objects, prolapsed bowel, or omentum following penetrating injury, known coagulopathy/liver disease, previous abdominal surgery, morbid obesity, and patients denying consent for FAST or DPL.

Remaining torso trauma patients were randomized using computer generated random number table to undergo either FAST (group A) or DPL (group B). All FAST exams were performed by the same surgeon (SK) throughout using $3.5 \mathrm{MHz}$ convex transducer. Time taken to perform FAST examination was noted. All DPLs were done by the same surgeon (AK) throughout by an open technique using infraumbilical midline $2-\mathrm{cm}$ vertical incision. DPL was considered grossly positive if $\geq 10 \mathrm{ml}$ of free blood, bile, or fecal matter was aspirated. Microscopically, presence of $\geq 100000 / \mu$ RBCs, $\geq 500$ WBCs, vegetative matter or fecal content and bacteria (on gram staining) were considered as positive DPL. Time taken to perform DPL and complications, if any, were recorded in each patient.

Thereafter, these patients were subjected to CECT scan of the abdomen, if required. Further treatment, operative or non-operative was decided based on a number of factors such as continuing blood loss, subsequent appearance of signs of peritonitis and free air on CECT abdomen.

All the details were recorded in a predesigned proforma. Outcome parameters were result of the intervention-test, therapeutic usefulness, time taken to perform the intervention-test and role in diagnosing bowel injury. In addition, mortality and cause of death were also evaluated. Data was expressed as either mean (+SD) or percent, as per the need. Tests applied were 2 proportion Z-test and chi-square. Significance was taken at $5 \%$.

\section{RESULTS}

Two hundred fifty consecutive eligible patients with torso trauma were enrolled into this RCT, with equal number of patients in both groups. However, 27 FAST group patients were excused for various reasons such as post-randomization equipment failure and patient's refusal for admission following initial treatment. Similarly, 23 DPL group patients were excused due to various reasons such as non-availability of DPL set, DPL being done by different surgeon and the use of local anesthesia without epinephrine.

Therefore, 200 patients remained for analysis: 98 in FAST group and 102 in DPL. Mean age of the patients was 28.3 years. There were 186 males with a demographic profile of the patients depicted in Table I. One hundred twenty four patients [road traffic injury $(R T I)=62$, fall from height $=36$, crush injury $=12$, blunt assault $=06$, industrial accident $=06$,

Table I. Demographic parameters of study subjects

\begin{tabular}{lcc}
\hline Demographic parameter & DPL $(\mathbf{n}=1 \mathbf{0 2})$ & FAST $(\mathbf{n = 9 8})$ \\
\hline Age range $(\mathbf{y r s})$ & $12-64$ & $13-55$ \\
Mean age $( \pm S D)$ & $27.86( \pm 12.77)$ & $28.78( \pm 11.07)$ \\
Male: Female ratio & $94: 8$ & $92: 6$ \\
Mode of injury & & \\
$\quad$ Blunt & 62 & 62 \\
$\quad$ Penetrating & 40 & 36 \\
\hline
\end{tabular}

DPL: Diagnostic peritoneal lavage; FAST: Focused assessment sonography in trauma; SD: Standard deviation. 
train accident $=02$ ] sustained blunt trauma while remaining 76 sustained penetrating trauma due to stabs. Random group wise, FAST group (total $n=98$ ) had RTI $(n=30)$, fall from height $(n=\mid 4)$, stabs $(n=36)$, crush injury $(n=08)$, blunt assault $(n=06)$, train accident $(n=02)$ and industrial accident $(n=02)$ as the causes of acute admission. Similarly, DPL group (total $n=102)$ had RTI $(n=32)$, fall from height $(n=22)$, stabs $(n=40)$, crush injury $(n=04)$ and industrial accident $(n=04)$ as the cause of acute admission.

Eighty four patients underwent exploratory laparotomy; 36 had sustained stab injury and 48 had sustained blunt trauma. Thus, from blunt trauma category $(n=124), 76$ were managed non-operatively and 48 underwent laparotomy. Similarly, from penetrating trauma category $(n=76), 40$ patients were managed non-operatively and 36 underwent exploratory laparotomy.

FAST was recorded as positive in 38 (38.7\%) and DPL was re- corded positive patients in $48(47 \%)$ patients. This difference was not statistically significant (Table 2 ).

The usefulness of FAST/DPL in guiding therapeutic decisions is shown in Table 3. A correct decision to operate was statistically similar when the results were positive. However, a negative DPL was significantly better than negative FAST in guiding for therapeutically beneficial laparotomy. Results were comparable for positive as well negative DPL or FAST when the patient underwent negative laparotomy or therapeutically non-beneficial but positive laparotomy. A positive FAST was significantly better than positive DPL in taking non-operative decisions. A negative FAST or DPL were comparable in guiding for non-operative treatment.

Bowel injury was found in 42 patients: 22 of these were in FAST group and 20 were in DPL group. Twelve of 22 patients in FAST group were test positive as against 18 from 20 in DPL group. Similarly, 10 of 22 from FAST group were test

Table 2. Results of the intervention test

\begin{tabular}{lccc}
\hline Test result & $\begin{array}{c}\text { Focused assessment } \\
\text { sonography in trauma }(\mathbf{n = 9 8})\end{array}$ & $\begin{array}{c}\text { Diagnostic peritoneal } \\
\text { lavage }(\mathbf{n = 1 0 2})\end{array}$ & $\mathbf{p}$ \\
\hline Positive & 38 & 48 & 0.237 \\
& & & 54 \\
Negative & 60 & Not significant) \\
\hline
\end{tabular}

Table 3. Therapeutic usefulness of FAST and DPL

\begin{tabular}{|c|c|c|c|c|c|c|}
\hline & $\begin{array}{c}\text { FAST } \\
(n=98)\end{array}$ & $\begin{array}{c}\text { DPL } \\
(n=102)\end{array}$ & $\mathbf{p}$ & $\begin{array}{c}\text { FAST } \\
(n=98)\end{array}$ & $\begin{array}{c}\text { DPL } \\
(n=102)\end{array}$ & $\mathbf{p}$ \\
\hline & $\begin{array}{l}\text { Positive } \\
(n=38)\end{array}$ & $\begin{array}{c}\text { Negative } \\
(n=48)\end{array}$ & & $\begin{array}{l}\text { Positive } \\
(n=60)\end{array}$ & $\begin{array}{c}\text { Negative } \\
(n=54)\end{array}$ & \\
\hline \multirow{3}{*}{$\begin{array}{l}\text { Therapeutically beneficial } \\
\text { (positive) laparotomy }\end{array}$} & $24^{\wedge}(04)^{\#}$ & $38^{\wedge}(08)^{\#}$ & $Z=1.61$ & $10 \sim$ & $02^{\sim}$ & $Z=2.25$ \\
\hline & & & $p>0.05$ & & & $p<0.05$ \\
\hline & & & (NS) & & & (SIG) \\
\hline \multirow[t]{3}{*}{ Negative laparatomy } & 0 & 0 & & $02 *(02)^{\#}$ & $04^{*}$ & $Z=0.97$ \\
\hline & & & & & & $p>0.05$ \\
\hline & & & & & & (NS) \\
\hline \multirow{3}{*}{$\begin{array}{l}\text { Therapeutically } \\
\text { non-beneficial } \\
\text { (positive) laparotomy }\end{array}$} & 0 & $04 * *$ & $Z=1.82$ & 0 & 0 & \\
\hline & & & $p>0.05$ & & & \\
\hline & & & (NS) & & & \\
\hline \multirow{3}{*}{$\begin{array}{l}\text { Conservative } \\
\text { management }\end{array}$} & 14 & 06 & $Z=2.65$ & $48(02)^{\#}$ & 48 & $Z=1.3$ \\
\hline & & & $\mathrm{p}<0.05$ & & & $p>0.05$ \\
\hline & & & (SIG) & & & (NS) \\
\hline
\end{tabular}

\#: Died (total deaths = 16; eight from FAST and eight from DPL); *: Laparotomy on progressive deterioration of patient proved to be entirely due to pelvic trauma; **: Though laparotomy revealed intraperitoneal solid viscus injuries, bleeding had stopped and thus laparotomy could have been avoided; : False negative FAST: could be because of early presentation, suboptimal test-skill or true handicap of the FAST. : False negative DPL: could be because of early presentation or true handicap of the DPL. ^Represents true positive: comparable. 
Table 4. Test results as against the bowel injury

\begin{tabular}{lccc} 
& \multicolumn{2}{c}{ Bowel injury $(\mathrm{n}=42)$} & $\mathbf{p}$ \\
\cline { 2 - 3 } & FAST & DPL & \\
\hline Positive & 12 & 18 & 0.011 (sig) \\
Negative & 10 & 02 & \\
\hline
\end{tabular}

FAST: Focused assessment sonography in trauma; DPL: Diagnostic peritoneal lavage.

Table 5. Mortality $(n=16)$

\begin{tabular}{lcc}
\hline & Blunt trauma & Penetrating trauma \\
\hline Laparotomy & $12^{\wedge}$ & $02^{*}$ \\
Non-operative & $02^{* *}$ & 0 \\
\hline
\end{tabular}

^: 04 FAST positive and 08 DPL positive; *: FAST positive; **: FAST negative.

negative and only two of 20 were test negative in DPL group. Therefore, DPL was significantly better than FAST in detecting bowel injuries (Table 4).

Fourteen patients died postoperatively, and two died on nonoperative management (total deaths 16). Fourteen belonged to blunt trauma group, and two belonged to penetrating injury group (Table 5). Operative or autopsy findings in these patients are shown in Table 6.
Eight were from FAST group. Six FAST positive patients underwent laparotomy that was justified due to the extensive intraperitoneal injuries; however, these patients died of postoperative morbidity (respiratory failure, sepsis and fat-embolism). Two were FAST negative and died of pelvic trauma and consequent hemorrhagic shock. Intra-peritoneal injuries were ruled out by autopsy in both patients.

A total of eight patients died in the DPL group and all were DPL positive and underwent laparotomy. Two of these had extensive retroperitoneal hematoma from pelvic fracture resulting in the DPL being positive association. Four patients were DPL positive for bowel contents. Two laparotomy patients were found to have small bowel perforation with gangrene while other two had gastric perforation and also underwent laparotomy. The remaining two patients underwent perihepatic packing but both died of continuing retroperitoneal blood loss from pelvic fracture; laparotomy was justified in these two patients too.

\section{Time Taken To Perform DPL and FAST}

Mean time taken to perform FAST and DPL was $2.53 \pm 0.52$ and 12.19 \pm 2.49 minutes, respectively. The difference was statistically significant $(p<0.001)$. There were no complication or technical difficulties attributable to DPL in any of 102 patients undergoing DPL.

\section{DISCUSSION}

As per the Advanced Trauma Life Support (ATLS) protocol, initial assessment of multiply injured patients involves clinical

Table 6. Operative findings and possible cause of death $(n=16)$

\begin{tabular}{|c|c|c|c|c|}
\hline No & Group & Injury & Time of death & Findings \\
\hline I & FAST+ & Penetrating & 12 days Post-op & Multiple gastric and colonic perforations \\
\hline 2 & DPL+ & Blunt & 03 days post-op & Pelvic fracture, hemo-pneumothorax \\
\hline 3 & DPL+ & Blunt & 04 days Post-op & Gastric perforation, liver laceration \\
\hline 4 & FAST- & Blunt & 6 hour post-injury & Pelvic fracture, pneumothorax \\
\hline 5 & FAST+ & Blunt & 03 day post-op & Pelvic fracture, mesenteric tear, bowel contusion \\
\hline 6 & FAST+ & Penetrating & 17 days post-op & Multiple bowel lacerations, diaphragm injury \\
\hline 7 & DPL+ & Blunt & 05 days post-op & Pelvic fracture, bowel perforation \\
\hline 8 & DPL+ & Blunt & 03 days post-op & Liver laceration, head injury \\
\hline 9 & FAST+ & Blunt & 10 days pot-op & Liver and spleen laceration, retroperitoneal hematoma \\
\hline 10 & DPL+ & Blunt & 02 days pot-op & Duodenal and pancreatic injury \\
\hline II & FAST- & Blunt & 13 hour post-injury & Pelvic fracture, bowel injury, suspected cardiac contusion \\
\hline 12 & DPL+ & Blunt & 03 days post-op & Liver laceration, bowel injury, pneumpothorax \\
\hline 13 & DPL+ & Blunt & 04 days post-op & Pelvic fracture, hemothorax, flail chest \\
\hline 14 & FAST+ & Blunt & 02 days post-op & Bowel injury, mesenteric tear, splenic laceration \\
\hline 15 & DPL+ & Blunt & 02 days post-op & Liver laceration, IVC tear, shattered kidney \\
\hline 16 & FAST+ & Blunt & 03 days post-op & Bowel injury, pulmonary contusion \\
\hline
\end{tabular}

DPL: Diagnostic peritoneal lavage; FAST: Focused assessment sonography in trauma. 
evaluation by $A B C D E$ approach along with use of adjuncts such as chest and pelvis X-Ray, FAST or DPL. Later, especially if immediate surgery is not warranted patients may be subjected to CT scan, laparoscopy, or observation. ${ }^{[3]}$ CT scan, useful in detecting otherwise occult injuries to both intra and retroperitoneal structures, has a high accuracy (about 95\%) and a very high negative predictive value (almost 100\%). ${ }^{[12]}$

FAST and DPL are bedside, economical, and rapid means of evaluation of trauma patients. Their greatest advantage lies in the fact that these do not interfere with ongoing resuscitation of the patient. ${ }^{[7]}$ There are relative merits and demerits to these two adjuncts. However, we believe that DPL offers several advantages over FAST such as no need for USG machine and trained man-power to perform and interpret the result, and its ability to differentiate blood and bowel contents which is not possible with FAST. ${ }^{[13]}$ Therefore, the declining role of DPL should be re-evaluated especially since our novel evidence demonstrates a convincing role for DPL as a superior technique to the FAST procedure in determination of blunt trauma. In this large RCT, we used 200 patients to investigate and compare the role of FAST and DPL in the management of truncal trauma. Most of our patients were males and young. This is consistent with the fact that young males are at the greatest risk of injuries. In our study, stabs constituted the single most common type of injury followed by RTI and fall from a height. To the best of our knowledge, this is the only study wherein this large number of stabbed patients has been studied. Further, in this study more than $50 \%$ of stabbed patients were managed non-operatively successfully. This proves that selective non-operative management of stab-abdomen is as successful as that following blunt trauma. We feel that this was possible due to a diligent clinical approach and appropriate use of FAST and/or DPL.

In this study, instead of studying the traditional parameters like sensitivity and specificity, and true positive and true negative values we studied and compared the role of FAST and DPL in taking decisions for laparotomy and conservative management. We feel that is is where the exact role of these investigations lies. On this parameter, positive FAST and DPL were comparable to each other in guiding the surgeon to therapeutically beneficial laparotomy. However, the fact that therapeutically beneficial laparotomy was performed in significantly larger number of patients with negative FAST than in situations with negative DPL indicates that overall, DPL is better than FAST in regulating therapeutically beneficial laparotomy. However, a positive FAST was a better determinant of successful non-operative management as compared to the positive DPL. A negative FAST or DPL was inferior to positive test results for dictating a successful non-operative management, but comparably so. For the remaining therapeutic outcomes (like negative laparotomy and therapeutically non-beneficial laparotomy) the results of FAST as well as DPL were comparable.
Further, in comparison to FAST, DPL proved to be significantly better in detecting bowel injuries. Also, fewer bowel injuries were missed by DPL as compared to FAST. Collectively, this suggests that since bowel injuries are common in blunt as well as penetrating trauma scenarios, the surgeon must keep the DPL as one of the important adjunct to primary survey. DPL can be a useful tool in the impact mortality ratio by detecting bowel injuries early.

Overall, 16 patients died. Six of these were FAST (true) positive, two FAST (true) negative and six were DPL (true) positive and two DPL (false) positive. Deaths in true positive DPL or FAST signifies ongoing bleeding and need to control the same to prevent an immediate death or late death on account of shock related complications. Two true negative FAST patients died of pelvic trauma, again highlighting the importance of arresting the ongoing bleeding. We had fewer deaths in penetrating trauma than the blunt trauma. This is definitely related to the promptness with which we handled our penetrating trauma patients, in contrast to the blunt trauma where it is not uncommon to miss intra-abdominal injuries. These results are a mandate to be extra-vigilant in blunt trauma patients.

A trained surgeon performed the FAST in this study. This has become an acceptable practice as the accuracy of surgeon and radiologist performed emergency ultrasonography has been shown to be comparable and high. ${ }^{[1,15]}$ Furthermore, both can perform comparable quality of FAST in comparable time. ${ }^{[16]}$ Our study too confirms that trained surgeons can reliably perform FAST. There is little doubt that DPL continues to be a reliable diagnostic adjunct in torso trauma, with $95.9 \%$ sensitivity, $99 \%$ specificity and $98.2 \%$ accuracy. ${ }^{[1]]}$

\section{Conclusions}

Although DPL requires significantly more time to perform, it is better than FAST as an adjunct for the initial assessment of a patient suspected to be having intra-abdominal injury.

Conflict of interest: None declared.

\section{REFERENCES}

1. Rozycki GS, Root HD. The diagnosis of intraabdominal visceral injury. J Trauma 2010;68:1019-23.

2. Hoff WS, Holevar M, Nagy KK, Patterson L, Young JS, Arrillaga A, et al. Practice management guidelines for the evaluation of blunt abdominal trauma: the East practice management guidelines work group. J Trauma 2002;53:602-15.

3. Feliciano DV. Diagnostic modalities in abdominal trauma. Peritoneal lavage, ultrasonography, computed tomography scanning, and arteriography. Surg Clin North Am 1991;71:241-56.

4. Byars D, Devine A, Maples C, Yeats A, Greene K. Physical examination combined with focused assessment with sonography for trauma examination to clear hemodynamically stable blunt abdominal trauma patients. Am J Emerg Med 2013;31:1527-8. 
5. Sheng AY, Dalziel P, Liteplo AS, Fagenholz P, Noble VE. Focused Assessment with Sonography in Trauma and Abdominal Computed Tomography Utilization in Adult Trauma Patients: Trends over the Last Decade. Emerg Med Int 2013;2013:678380.

6. Kirkpatrick AW, Ball CG, D’Amours SK, Zygun D. Acute resuscitation of the unstable adult trauma patient: bedside diagnosis and therapy. Can J Surg 2008;51:57-69.

7. Radwan MM, Abu-Zidan FM. Focussed Assessment Sonograph Trauma (FAST) and CT scan in blunt abdominal trauma: surgeon's perspective. Afr Health Sci 2006;6:187-90.

8. Smith J. Focused assessment with sonography in trauma (FAST): should its role be reconsidered? Postgrad Med J 2010;86:285-91.

9. Amer MS, Ashraf M. Role of FAST and DPL in assessment of blunt abdominal trauma. Prof Med J 2008;15:200-4.

10. Day AC, Rankin N, Charlesworth P. Diagnostic peritoneal lavage: integration with clinical information to improve diagnostic performance. J Trauma 1992;32:52-7.

11. Blow O, Bassam D, Butler K, Cephas GA, Brady W, Young JS. Speed and efficiency in the resuscitation of blunt trauma patients with multiple injuries: the advantage of diagnostic peritoneal lavage over abdominal computerized tomography. J Trauma 1998;44:287-90.

12. Stapp JP. Human tolerance to deceleration. Am J Surg 1957;93:73440.

13. Henneman PL, Marx JA, Moore EE, Cantrill SV, Ammons LA. Diagnostic peritoneal lavage: accuracy in predicting necessary laparotomy following blunt and penetrating trauma.J Trauma 1990;30:1345-55.

14. McKenney MG, McKenney KL, Compton RP, Namias N, Fernandez L, Levi D, et al. Can surgeons evaluate emergency ultrasound scans for blunt abdominal trauma? J Trauma 1998;44:649-53.

15. Thourani VH, Pettitt BJ, Schmidt JA, Cooper WA, Rozycki GS. Validation of surgeon-performed emergency abdominal ultrasonography in pediatric trauma patients. J Pediatr Surg 1998;33:322-8.

16. Velmahos GC, Demetriades D, Stewart M, Cornwell EE 3rd, Asensio J, Belzberg H, et al. Open versus closed diagnostic peritoneal lavage: a comparison on safety, rapidity, efficacy. J R Coll Surg Edinb 1998;43:235-8.

17. Meyer DM, Thal ER, Weigelt JA, Redman HC. Evaluation of computed tomography and diagnostic peritoneal lavage in blunt abdominal trauma. J Trauma 1989;29:1168-72.

\section{KLINIK ÇALIŞMA - ÖZET}

Travma olayında vücut travmasında birincil araştırmaya ek olarak tanısal periton lavaj (DPL) sıvısı ile travmaya odaklanmış ultrasonografi değerlendirmesinin (FAST) karşılaştırması: Bir prospektif randomize klinik çalışma

\section{Dr. Sunil Kumar, Dr. Abhay Kumar, Dr. Mohit Kumar Joshi, Dr. Vinita Rathi}

Tıp Bilimleri Üniversite Koleji, Cerrahi Bölümü, Delhi, Hindistan

AMAÇ: Son zamanlarda birincil araştırmaya ek olarak tanısal periton lavajına (DPL) göre travmaya odaklanmış ultrasonografi değerlendirmesi (FAST) tercih edilmektedir. Ancak herhangi bir randomize çalışma olmadığından kanıtlara dayalı bir bulgu değildir.

GEREÇ VE YÖNTEM: Çalışmaya dahil edilme kriterlerini karşılayan 200 ardışık beden travması hastası ya DPL, ya da FAST'ye randomize edildi. Sonuçlar daha sonra ya kontrastla güçlendirilmiş bilgisayarlı tomografi (BT) (cerrahi dışı yöntemlerle tedavi edilen hastalar) veya laparotomi (cerrahi tedavi geçiren hastalar) bulgularıyla karşılaştırıldı. Sonuç parametreleri: Test sonucu, tedavinin yararlılığı, bağırsak yaralanmasının tanısındaki rolü ve prosedürü uygulamak için geçen zaman idi.

BULGULAR: Yaş ortalaması 28.3 yıl olan, FAST grubunda 98 ve DPL grubunda 102 kişi olmak üzere 200 hasta incelendi. Yüz dört kişi künt travmaya, 76 kişi bıçaklanma sonucu delici travmaya maruz kalmış olup 38'i (\%38.7) FAST ve 48’i (\%47) DPL pozitif idi ( $p=0.237$, anlamlı değil). Tedavi olarak yararlı laparotomiye kılavuz olma açısından negatif DPL, negatif FAST'tan daha iyi idi. Cerrahi dışı kararlar için pozitif FAST, pozitif DPL'den anlamlı derecede daha iyi idi. Bağırsak yaralanmalarının tespiti ve atlanmaması açısından DPL, FAST'den daha iyi idi. DPL'yi uygulama, FAST'yi uygulamaya göre anlamlı derecede daha fazla zaman almıştı.

TARTIŞMA: Bu çalışma, DPL'nin FAST'den daha iyi olduğunu göstermektedir.

Anahtar sözcükler: Tanısal periton lavajı; travmaya odaklanmış ultrasonografi değerlendirmesi; beden travması.ı.

Ulus Travma Acil Cerr Derg 2014;20(2): I01-106 doi: 10.5505/tjtes.2014.37336 